\author{
Srđan Ljubojević, \\ kapetan, dipl. inž \\ Vojna akademija - Odsek logistike,
}

\section{STRATEGIJA MARKETING-MIKSA U
OBEZBEĐIVANJU KADROVA SAOBRAĆAJNE \\ STRATEGIJA MARKETING-MIKSA U
OBEZBEĐIVANJU KADROVA SAOBRAĆAJNE SLUŽBE VOJSKE}

UDC: $658.8: 355.23: 356.257$

Rezime:

Aktuelni reformski procesi u Vojsci Srbije prilika su za postavljanje novih principa, kada je u pitanju spoj marketinga $i$ vojne organizacije. $U$ ovom radu prikazan je mogući izgled instrumenata marketing-miksa u funkciji obezbeđivanja kadrovskih resursa saobraćajne službe Vojske Srbije, sa namerom da se definiše opšti izgled instrumenata $u$ marketing-aktivnostima.

Ključne reči: marketing, marketing-miks, kadrovi.

\title{
THE MARKETING MIX STRATEGY WITHIN ARMY \\ TRANSPORTATION SERVICE PERSONNEL PROVIDING
}

Summary:

The presently relevant reform processes in the Military of Serbia are an opportunity for seting new principles when we are talking about marketing - military organization joint. In this work a possible look of marketing mix instruments is presented wich purpose is to provide meanning resources of transportation service in the Military of Serbia, with intention to define a general look of the instruments in marketing activities.

Key words: marketing, marketing mix, personnel.

\section{Uvod}

Savremeno poslovanje nosi veliki broj elemenata stohastičnosti. Stoga nijedno preduzeće nije sigurno u pogledu verovatnoće ostvarivanja sopstvenih želja i realizacije poslovnih odluka. Jedan od najuticajnijih faktora okruženja, koji direktno utiče na poslovanje preduzeća, jeste tržište. Sa aspekta pojedinačnog ponuđača tržište se može definisati i kao ,agregatna tražnja potencijalnih kupaca jednog proizvoda ili usluge" [1]. Na tržištu se dobija jedina merodavna ocena opravdanosti i ispravnosti poslovnih poduhvata. Marketing, kao najuočljivija po- slovna funkcija za potrošača, bazno je vezan za tržište.

U savremenom poslovanju ideja vodilja proizvođača nije više proizvodnja proizvoda za koji treba naći kupca, već proizvodnja proizvoda prema zahtevima i mogućnostima tržišta. Usled šarolikosti i kompleksnosti tržišta, rentabilna mogu biti samo ona preduzeća koja, na osnovu ispravnog definisanja tržišta, utvrđivanja njegovih dimenzija i izvršene segmentacije, izvrše pravilan izbor ciljnog segmenta i, uz adekvatnu marketing-strategiju, usredsrede sve svoje marketinške aktivnosti na zadovoljenje potreba izabranog tržišnog segmenta. 
Naizgled jednostavan i lako razumljiv, marketing se, pogrešno, najčešće poistovećuje sa reklamom i prodajom. Iako je nastao kao odgovor na probleme proizvodnje i proizvođača, danas je suština marketinga $u$ rešavanju problema potrošača. Pojam marketing je anglosaksonskog porekla (eng. market - tržište) i znači „stavljanje na tržište“ ili ,stvaranje tržišta“. Ne postoji adekvatan prevod ovog pojma, kao što ne postoji ni opšteprihvaćena definicija marketinga.

Prema Američkom udruženju za marketing (American Marketing Assotiation - AMA), marketing je proces planiranja i sprovođenja koncepcija, cena, promocije i distribucije ideja, robe i usluga, $\mathrm{u}$ kojem se kreira razmena koja zadovoljava potrebe pojedinaca i organizacija [2].

Svakodnevne intenzivne promene $\mathrm{u}$ okruženju doprinose konstantnom proširivanju i produbljivanju pojma marketinga, tako da se on danas definiše kao proces obezbeđenja optimalnog nivoa zadovoljenja potrošača, uz ostvarenje optimalnog profita za preduzeće i optimalnog finansijskog i radnog zadovoljstva za sve zaposlene u preduzeću (stvaranje sistema vrednosti za zaposlene), i sve to bez oštećenja fizičkog i socijalnog okruženja [1]. Većina definicija marketinga apostrofira zadovoljenje potreba i želja potrošača u procesu razmene na tržištu, mada se poslednjih godina, sve više, naglašava društvena dimenzija marketinga i jačanje društvene odgovornosti preduzeća u fizičkom i socijalnom okruženju. Ali, bez obzira na aspekt posmatranja, marketing-koncept predstavlja kontinuiran proces, a ne jednokratnu ili povremenu aktivnost u savremenom menadžmentu.
U okviru aktivne reforme Vojske Srbije (Vojske) u njen sistem potrebno je ugraditi i adekvatnu marketing-koncepciju, koja će joj doneti atribut moderne, prožimajući sve njene slojeve, pa i njenu saobraćajnu službu ( $\mathrm{SbSl}$ ), jer savremeni svetski bezbednosni trendovi nameću potrebu za reformama i unapređenjem, ne samo materijalno-tehničke prirode, već i kadrovskog potencijala.

\section{Instrumenti marketinga (marketing-miks)}

Podrazumevajući da je marketing koncepcija poslovnog odlučivanja, po kojoj se dobit preduzeća vezuje za njegovu sposobnost da shvati potrebe potrošača i da instrumente svoje poslovne politike bira shodno dugoročnim interesima potrošača, sasvim je logično da planiranje u poslovanju bude usmereno ka trendovima promena u obimu i strukturi tržišnih potreba. Pri tome suštinska uloga marketinga je da uspostavi i održava komunikaciju, u najširem smislu te reči, između proizvođača i potrošača.

Instrumenti marketinga (tzv. marketing-miks) koriste se $\mathrm{u}$ ostvarivanju uticaja na izbor potrošača, otklanjanjem transakcionih barijera, putem nezavisnog ili međusobno uslovljenog doprinosa. Otklanjanjem transakcionih barijera marketing-miks ostvaruje operativne ciljeve marketing-strategije, pa se posmatra i kao operativna strana marketing-koncepcije. Odnos instrumenata marketinga $u$ marketing-miksu može biti konkurentski, komplementaran ili supstitutivni.

Sam termin marketing-miks pojavio se 1964. godine i tada je obuhvatao planiranje proizvoda, prodajnu cenu, brend, 
distributivne kanale, prodaju, reklamiranje, promocije, pakovanje proizvoda, plasman proizvoda, rukovanje proizvodom i analiziranje. Kasnije su ove komponente grupisane u četiri kategorije, danas poznate kao $4 \mathrm{P}$ marketing miksa: eng. Product - proizvod, Price - cena, Place - distribucija i prodaja i Promotion - promocija [3].

Moderan marketing vidi marketing-miks kao skup marketing-instrumenata, koje preduzeća koriste $\mathrm{u}$ ostvarivanju svojih marketinških ciljeva na ciljnom tržištu [2]. Suštinski, to je ono što tržište kupac dobija od preduzeća, kao rezultat svih napora preduzeća da zadovolji potrebe kupaca. Kombinacija elemenata u marketing-miksu daje ponudi preduzeća kvalitet više i kod kupaca stvara odgovarajuću sliku (imidž) o preduzeću i proizvodu. Pitanje izbora instrumenata za marketing-miks, optimalne kombinacije tih instrumenata i faktora koji utiču na nju specifični su za svaku delatnost i svako konkretno preduzeće.

Savremeni marketing-koncept, sa težištem na potrošaču, ne razmatra marketing-miks kao 4P proizvođača, već kao $4 \mathrm{C}$ potrošača (Customer needs and wants - potrebe i želje potrošača, Cost to the consumer - troškovi kupaca, Convenience - ugodnost za potrošače i Communication - komuniciranje). S druge strane, produbljivanje izvornog pristupa marketing-miksu evoluiralo je $\mathrm{u}$ proširivanje spiska njegovih instrumenata sa $4 \mathrm{P}$ na $7 \mathrm{P}$, kod organizacija u uslužnim delatnostima, dodajući People - ljude, Process procese pružanja usluga i Physical evidence - fizičku sredinu u kojoj se usluga pruža [3], ali i 3C (Consumerism - obez- beđenje dugoročnih interesa potrošača, Control - kontrolu i racionalno korišćenje resursa i Conservation - očuvanje okoline) [1].

Praksa je pokazala da prava kombinacija instrumenata marketinga, u pravilno doziranom marketing-miksu, daje bolje rezultate od opredeljivanja za samo jedan instrument. Pri tome, svako preduzeće mora pratiti promene u skupu faktora koji definišu prirodu uloge pojedinih instrumenata u marketing-miksu.

Statički pristup oblikovanju marketing-miksa je neefikasan, jer su vrednosti i efekti pojedinih instrumenata vremenski ograničeni. Stoga, jednom formirana kombinacija marketing-miksa treba da predstavlja okvir u kojem će se, shodno dinamici promena uslova poslovanja, menjati i međusobni odnosi pojedinih instrumenata u marketing-miksu, ali i njihovo prisustvo.

Bez obzira na vrstu delatnosti i uslove u okruženju, u marketing-miksu svakog preduzeća su, modifikovana ili ne, uvek prisutna četiri osnovna instrumenta (4P) ili, bolje rečeno, odgovarajući miks svakog od instrumenata.

\section{Primena marketing-miksa u obezbeđenju kadrova za potrebe saobraćajne službe Vojske Srbije}

Optimalna kombinacija instrumenata marketing-miksa bitno je uslovljena karakterom delatnosti, odnosno tržištem na kojem preduzeće obavlja svoju poslovnu aktivnost.

Vojska, kao organizacija koja se finansira isključivo iz budžeta i kojoj je primarni cilj sprovođenje njene odbram- 
bene misije, a ne ostvarenje profita, može se smatrati neprofitnom organizacijom. Aktivnosti SbSl, kao nosioca saobraćajne podrške Vojske, raznolike su i podrazumevaju, pored ostalog, i školovanje i razvoj kadrova za sopstvene potrebe. S obzirom na karakter delatnosti $\mathrm{SbSl}$, uz epitet neprofitne, može se pripojiti i epitet uslužne organizacije, sa svim aspektima marketinga specifičnog za uslužni i neprofitni sektor.

Poznato je da su ljudski resursi najvažniji, dinamički, kreativni i inovativni element proizvodnje usluga iz oblasti saobraćaja, ali i logističkih usluga u vezi sa saobraćajem. Jedino obrazovan, osposobljen, iskusan, vešt i motivisan kadar iz oblasti saobraćaja može omogućiti sigurne, brze i racionalne procese proizvodnje saobraćajnih, odnosno logističkih usluga.

Specifičnost delatnosti, uz sve druge ograničavajuće faktore, pred SbSl stavlja problem obezbeđenja kadrova potrebne stručnosti i kvalifikacije. Ponajviše zbog toga, ali imajući u vidu i činjenicu da obrazovanjem sopstvenog kadra organizacija povećava svoj ljudski kapital, SbSl Vojske se opredelila da kadar za sopstvene potrebe, u najvećoj meri, samostalno školuje. Usled specifičnosti radnih zadataka u saobraćajnoj podršci Vojske, angažovanje kadra iz građanstva veoma je ograničeno, tako da se gotovo celokupna strategija obezbeđenja kadrova za potrebe SbSl oslanja na školovanje kadrova u Srednjoj vojnoj školi i Vojnoj akademiji (VA). Pri tome je jedino kadar školovan u VA projektovan i za upravne nivoe u hijerarhiji SbSl.

Protekle decenije se vojna organizacija, a u okviru nje i SbSl, suočila sa nizom problema upravo u obezbeđenju tog kadra. Danas je ona primorana da, u procesu re- formi, nađe rešenje koje će joj obezbediti kontinuiran priliv kvalitetnog kadra.

U tom smislu i u okviru strategijskih opredeljenja, SbSl Vojske danas, nužno, mora da prihvati savremeni marketinški koncept i definiše adekvatnu marketing-strategiju. Dosadašnje marketinške aktivnosti SbSl, na području obezbeđenja kadrova, nisu dale očekivane rezultate. Naravno, ni jedna marketing-strategija ne može dati pozitivne rezultate na duži period, ako nije podržana kvalitetom i rezultatima ostalih poslovnih funkcija. Aktuelni reformski tokovi u SbSl Vojske su, ujedno, prilika da se i marketing, na adekvatan način, uključi u kreiranje savremene i moderne saobraćajne podrške vojne organizacije.

Pri tome, polaznu tačku svih aktivnosti predstavlja tržište. Država, kao donator, nepromenljiv je faktor u funkcionisanju Vojske, tako da je izlišno govoriti o tržištu donatora. Ali, sa aspekta školovanja u Vojsci, ,potrošačko“ tržište je geografski omeđeno teritorijom Republike Srbije, a ciljni segmenti su okvirno vezani za starosnu dob stanovništva od petnaeste do tridesete godine života. Naime, kadrovski interesantna populacija za SbSl Vojske je populacija mladih ljudi, prvenstveno muškog pola, a u skladu sa savremenim trendovima i ženskog, koji se školuju u odgovarajućim srednjim, višim školama i fakultetima, ili onih koji su to školovanje završili.

Adekvatna tržišna istraživanja i osamostaljenje funkcije marketinga SbSl, u smislu odvajanja marketinga SbSl od marketinga ostalih službi u Vojsci, polazne su pretpostavke pri definisanju osnovnih instrumenata marketing-miksa VA (slika 1), kao ustanove u kojoj se školuje najveći deo kadrovskog potencijala SbSl. 
Sa aspekta školovanja kadra SbSl u VA, proizvod (usluga), koji u marketing-miksu VA može da ponudi tržištu, predstavlja visokoškolsko obrazovanje. Trenutno, VA nema tržišno prepoznatljiv proizvod, uprkos njegovoj specifičnosti u odnosu na slične proizvode konkurenata (Saobraćajnog fakulteta Univerziteta $u$ Beogradu ili Fakulteta tehničkih nauka Univerziteta $\mathrm{u}$ Novom Sadu). Analiza konkurentskih proizvoda nameće potrebu za modernizovanjem sistema školovanja u VA, diferencijaciju programa školovanja i izgradnju prepoznatljivog imidža.

Neophodnost pribavljanja dovoljno dobrih i upotrebljivih sekundarnih podataka o potencijalnim kadrovskim resursima i njihovim željama, zahtevima i stavovima, upućuje i na intenzivnija tržišna istraživanja. Pri tome, u formulisanju konačne ponude, korisnija su sopstvena $\mathrm{i}$ „naručena“ istraživanja stavova građana (u vidu anketa ili nekom drugom metodom) od oslanjanja na podatke drugih institucija i ustanova. U tim istraživanjima moraju biti obuhvaćeni ne samo ciljni segmenti već i šira populacija, koja u velikoj meri utiče na stavove i donošenje konačne odluke ciljnih segmenata.

Ključno pitanje u definisanju ,proizvodne" ponude VA jeste: šta ponuditi kao „nešto više“ koristi od onoga što ciljni segment očekuje i kako istaći diferenciranost svog programa u odnosu na konkurenciju?

Odgovor treba tražiti, najpre, $\mathrm{u}$ isticanju postojećih specifičnosti školovanja u VA, uslovljenih prirodom poslova za koje se kadar i školuje, a zatim i u inoviranju i obogaćivanju sadržaja školovanja. U tom smislu, svrsishodno je istaći da

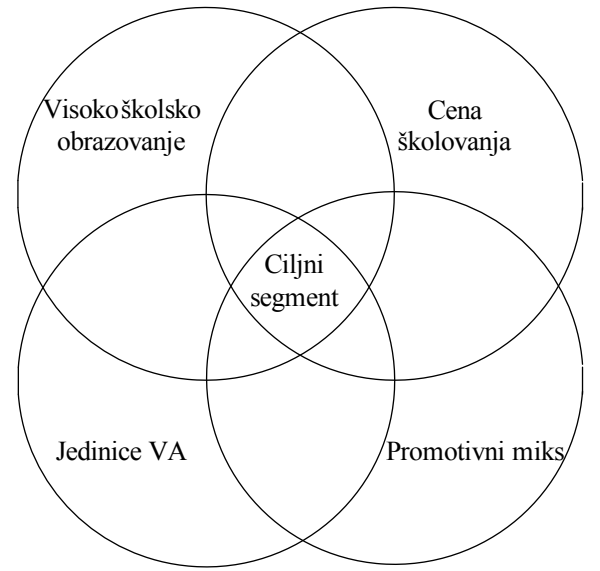

Sl 1. - „4P“ marketing-miksa Vojne akademije

sam pojam akademija podrazumeva ne samo znanja, već i njihov spoj sa veštinama i sposobnostima. Ono što u školovanju kadrova saobraćajne struke ponudu VA diferencira od konkurentnih ponuda su, svakako, raznovrsni sadržaji obuke, koji su, provereno, interesantni ciljnim segmentima i koji se odnose na polaganje vozačkog ispita za upravljanje vozilima A, B, C i E kategorije, obuku u skijanju, obuku u upravljanju motornim vozilima u zimskim i terenskim uslovima, obuku u plivanju, u borilačkim veštinama, opštu vojnu obuku u zimskim i letnjim uslovima i slično. Zatim, kao argument diferencijacije svoje ponude i stvaranje preferencije na ciljnim tržištima treba istaći i mogućnost pohađanja niza sve prisutnijih i, kadru SbSl koji se školuje u VA, dostupnijih, kurseva različitog sadržaja (kursevi stranih jezika, kurs padobranstva, kurs mačevanja, itd.). U skladu sa reformama sistema odbrane, otvorena je i mogućnost školovanja u inostranstvu (u najprestižnijim vojnim akademijama svetskih vojnih sila), za onaj kadar koji pokaže potreban kvalitet. 
Ovi specifični sadržaji, naravno, nisu dovoljni da kreiraju ,vrednost više“ samo ako su zadovoljeni osnovni nivoi svake usluge. Drugim rečima, potrebno je obezbediti visok kvalitet osnovnog obrazovnog procesa (bazičnog programa), kroz kvalitetan nastavni kadar, kvalitetan i savremen nastavni program, kao i bogatu $\mathrm{i}$ savremenu materijalnu nastavnu bazu.

$\mathrm{Na}$ ovaj način formiran proizvod usluga u tržišnoj ponudi lako je prepoznatljiv i olakšano je njegovo pozicioniranje. Mogućnosti inoviranja proizvoda su, takođe, velike (proširivanje saradnje sa srodnim fakultetima i školama u zemlji i inostranstvu, intenziviranje učešća u raznim projektima, naučnim i stručnim skupovima, učešća u humanitarnim akcijama, studijska putovanja, saradnja sa inostranim vojnim akademijama, uključivanje u međunarodne bezbednosne tokove i sl.), a posebne pogodnosti, u vidu usluga smeštaja, ishrane, korišćenja biblioteke i ostalih pratećih usluga školovanja, ali i obezbeđenje radnog mesta odmah po završetku školovanja, bacaju posebno svetlo na ponudu VA. Pri tome, i proces pružanja ovih usluga mora biti visoko kvalitetan, jer je on od presudnog značaja za formiranje satisfakcije potrošača - korisnika i izgradnju odgovarajućeg imidža organizacije i usluge.

U kreiranju imidža organizacije i proizvoda, „opipljivi“ elementi usluge imaju ogromnu ulogu, jer upućuju na visok kvalitet usluge. Vojna akademija i SbSl Vojske već imaju formirane simbole (ambleme), koje uz druge „opipljive“ elemente (adekvatnu boju, fizički ambijent, osoblje, opremu, promotivni materijal...) samo treba učiniti prepoznatljivim. Ali, da bi imidž bio u potpunosti izgra- đen i održiv neophodno je da i status pripadnika SbSl i Vojske u celini bude na kvalitativno višem nivou.

Ovako formulisan proizvod VA, uz izgrađen potrebni imidž, veoma je konkurentan na tržištu. Ali, on ima i visoke „proizvodne“ troškove. Aktuelni vremenski trenutak u mnogim segmentima onemogućava formiranje ovakvog proizvoda. S obzirom na potrebu za kontinuiranim prilivom kadra, $\mathrm{SbSl}$ je primorana da obezbeđenju željenih karakteristika proizvoda pristupi kao srednjoročnom ili dugoročnom cilju.

S obzirom na neprofitni karakter organizacije i na činjenicu da školuje kadar za sopstvene potrebe, veoma upotrebljiv instrument marketing-miksa, radi ostvarenja konkurentske prednosti, može biti cena. U prilog tome govori i činjenica da, zbog visokog percipiranog rizika pri kupovini usluga, potrošači često cenu, kao vidljiv element upoređivanja različitih usluga, koriste i kao važan kriterijum pri odlučivanju (pretpostavljajući da viša cena podrazumeva i viši kvalitet). Stoga, viša cena školovanja kadra saobraćajne struke u VA, u odnosu na konkurentske cene, može predstavljati prednost, ako se na pravi način prezentuje. Ne treba zapostaviti ni ulogu, neke vrste „kreditiranja“ pri realizaciji - naplati utvrđene cene. Naime, naplata nije novčanog karaktera, sem u slučajevima kada dođe do prekida saradnje u pružanju usluge (što zavisi od volje i osećaja odgovornosti korisnika) ili do prekida poslovne saradnje nakon realizovane usluge. Konkretnije, kako je usluga školovanja u VA usluga visokog kontakta, koja zahteva prisustvo i angažovanje korisnika u procesu pružanja 
usluge, i sam korisnik ima odgovarajuće obaveze. Za uzvrat, omogućeno mu je da cenu isporučene usluge plati po njenoj realizaciji, i to ne novcem, već svojom radnom angažovanošću u predviđenom periodu.

Ono što je karakteristično za instrument cene u obrazovnoj ponudi VA jeste nemogućnost diferenciranja cene usluge, ni po kojem osnovu, osim na bazi različite verzije usluge (školovanje u VA, školovanje $\mathrm{u}$ inostranim vojnim akademijama i sl.). Dakle, nije moguće diferenciranje cene na osnovu različitih grupa korisnika usluge, niti na bazi lokacije pružanja usluge ili različitog vremena korišćenja usluge...

Sa aspekta distribucije usluge, pružanje usluge u slučaju školovanja kadra SbSl vezano je za VA i lokaciju njenih organizacijskih jedinica. Specifičnost i priroda usluge VA ne omogućavaju lokalnu pristupačnost usluge, niti decentralizaciju u pružanju usluge, usled enormnog povećanja troškova i nerentabilnosti takvog distributivnog rešenja. Ni preispitivanje trenutne lokacije pružanja usluge (grad Beograd) nije potrebno, jer pozitivni efekti, u slučaju predislokacije VA, nisu značajni, a ne idu ni u prilog imidžu organizacije.

Drugi aspekt distributivnog miksa angažovanje posrednika u distributivnom kanalu, takođe nije moguć u konkretnom slučaju. Usled visokospecijalizovane usluge i mogućnosti narušavanja očekivanih standarda u kvalitetu usluge, direktna isporuka usluge je, trenutno, najbolje i jedino rešenje. U prilog tom rešenju govori i ograničen broj korisnika usluge (samo nekoliko desetina na kon- kursu odabranih korisnika). Čak ni indirektno pružanje usluga (uz pomoć tehnoloških dostignuća, kao posrednika) nije moguće, usled karaktera usluge.

Dakle, distribucija je veoma ograničen instrument marketing-miksa, kada su u pitanju usluge školovanja kadrova SbSl u VA. Za razliku od distribucije, instrument promocije je veoma širok.

Promotivni miks, ne samo SbSl i VA, već i celokupne vojne organizacije je, do sada, podrazumevao nekoliko ustaljenih promotivnih oblika, koji su, uz to, bili i nedovoljno eksploatisani. Pored ostalog, posledica takvih marketinških aktivnosti je i nedovoljna obaveštenost građana o Vojsci i dešavanjima u njoj i visoka nezainteresovanost za pitanja koja se tiču Vojske i odbrane. Prema određenim istraživanjima [4], sprovedenim poslednjih godina, tek svaki osmi građanin (12\% punoletne populacije) pokazuje interesovanje za pitanja koja se tiču Vojske, a svaki treći ( $30 \%$ populacije) smatra ove teme potpuno neinteresantnim. U preostalih $58 \%$ su oni koji pokazuju ,donekle“ ili „malo“ interesovanje. Indikativno je da je isto toliko građana (69\%) „loše“ i ,veoma loše" obavešteno o događajima u Vojsci, dok je gotovo zanemarljiv broj onih koji su „dobro“ informisani $(2,5 \%)$.

Ovi rezultati nedvosmisleno ukazuju na probleme u komunikaciji na relaciji Vojska - građani. U okviru novog marketinškog pristupa Vojska Srbije mora iskoristiti sve promotivne mogućnosti ne bi li promenila lošu komunikacionu sliku. Pri tome, ciljna grupa treba da bude prvenstveno 58\% „malo“ ili „donekle“ zainteresovanog stanovništva. 
U uslovima globalizacije medija, programa i publike, kada je postignuto trenutno i neposredno obaveštavanje o zbivanjima $u$ svim delovima društva, javno mnjenje se brzo formira i menja. Imajući to u vidu, ali i činjenicu da je uticaj javnosti na vojsku sve veći, nastojanja savremenih vojski da pridobiju poverenje ciljnih grupa u društvu postaju izraženija. Usko vezan sa nastojanjima da se pridobije naklonost javnosti jeste i imidž vojne organizacije. U skladu s tim, sistem komuniciranja vojne organizacije sa javnošću ima komponente usmerene na interno i eksterno komuniciranje (slika 2).
Eksterno komuniciranje Vojske sa javnošću je, prema istraživanjima, u velikoj meri neefikasno. Za oko $50 \%$ građana najvažniji izvori informisanja javnosti [4] su „lično iskustvo iz Vojske“ i ,poznanici koji su sada u Vojsci ili su skoro napustili Vojsku“. Mediji (televizija, novine, radio, časopisi...) učestvuju u informisanju javnosti sa svega $35 \%$, dok veliki broj ispitanika (15\%), „ne zna“ koji izvor saznanja je za njih „najvažniji“. Slika je još više poražavajuća kada se analiziraju odgovori na pitanje poverenja u izvore saznanja (gotovo 30\% ispitanika

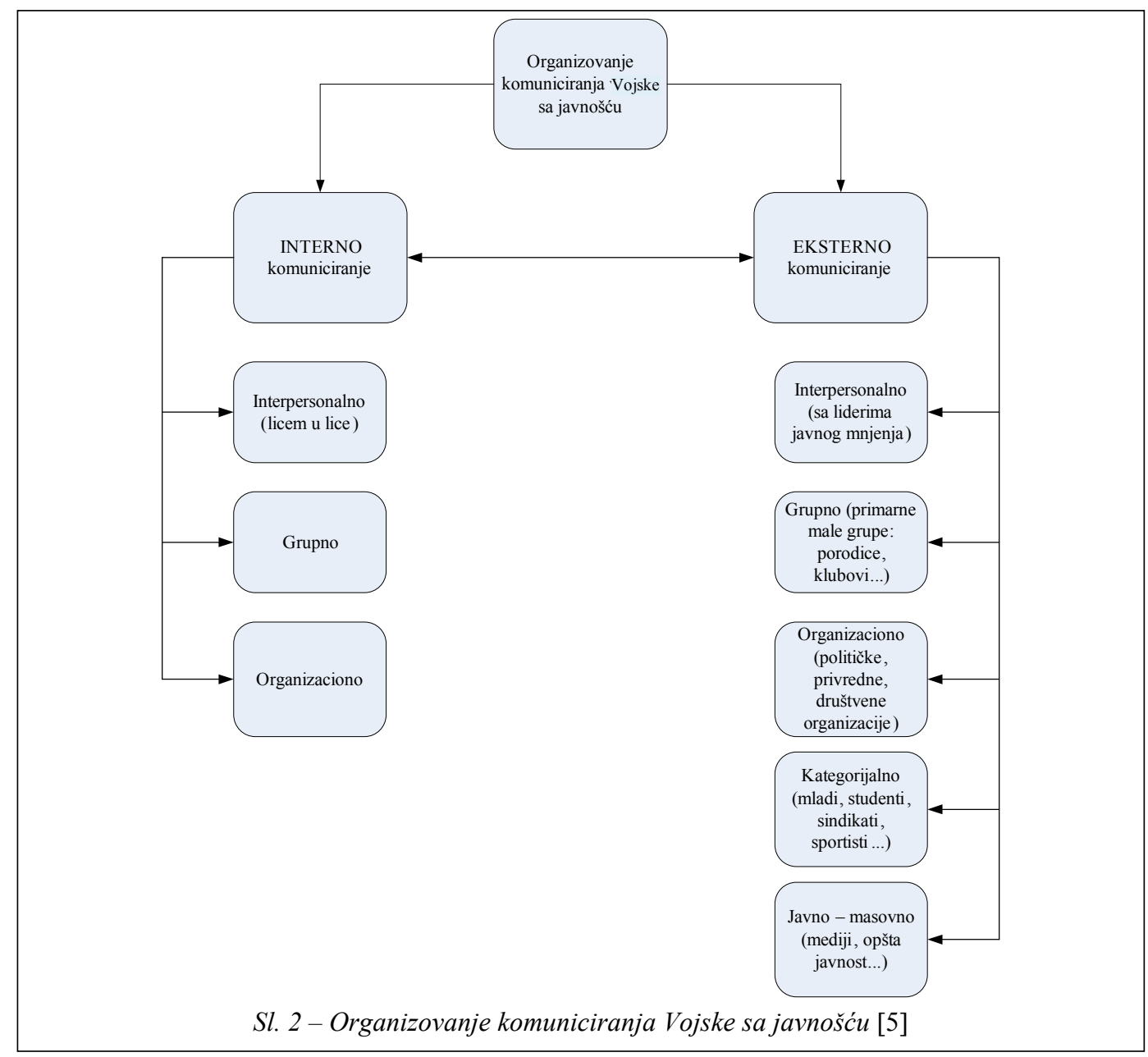


„ne veruje ni jednom izvoru“ ili „ne zna kome da veruje"). Postavlja se pitanje: šta je uzrok ovolikoj skeptičnosti i sumnjičavosti prema informacijama koje se tiču Vojske?

Logično je da postoji zavisnost između interesa javnosti $\mathrm{i}$ istinitosti, tačnosti, ali i tajnosti vojnih informacija i podataka. Posebni timovi u službama za odnose sa javnošću Ministarstva odbrane i Generalštaba Vojske odgovorni su za obezbeđivanje uverljivih i tačnih podataka i informacija u odnosima sa ciljnim grupama, ali i za izbor pravog načina prenošenja tih informacija.

Postoje najmanje dva gledišta koja se odnose na prava na informacije vezane za Vojsku. Prema jednom, svaki građanin ima pravo na dostupnost informacija i podataka u vezi sa sistemom odbrane, jer je dužnost države, Vojske i medija da ga o tome pravovremeno obaveštavaju. $\mathrm{Na}$ osnovu drugog pristupa, država ima prioritet $\mathrm{u}$ odnosu na građane, usled čega zadržava pravo da javnosti prenese samo informacije za koje ona proceni da su neophodne. U prvom slučaju evidentan je koncept dvosmernog komuniciranja, koji je poželjan, a u drugom jednosmerni oblik koji je, naravno, nepoželjan. Vojne informativne službe komuniciraju sa javnošću uglavnom posredstvom mas-medija, zapostavljajući druge nivoe informisanja (međusobni, grupni...) i zanemarujući, tako, kanale koji omogućavaju povratni tok kritičkih i inovacijskih poruka. Komunikacioni proces je, na taj način, podložan formalizaciji, a informacije koje se objavljuju su faktografske, selektovane i neinteresantne za javnost. Ovaj problem u komunikaciji uočilo je i $65 \%$ građana [4].
Posledica takve komunikacije je i moguća pogrešna slika javnosti o Vojsci. Naime, tematski sadržaj komuniciranja se u preko $60 \%$ slučajeva odnosi na reformu Vojske, priključivanju Partnerstvu za mir i ratno nasleđe, vezano za Haški tribunal... S druge strane, teme koje su interesantne za javnost (preko 30\% zainteresovanih) tiču se svakodnevnih aktivnosti Vojske, obuku, vežbe, školovanje, standard i status njenih pripadnika [4]. Jasno je da samo autonoman informaciono-komunikacioni sistem može da realizuje funkciju brzog, dinamičnog, dvosmernog i višestranog protoka informacija. To je pretpostavka prevazilaženja uočenih komunikacijskih problema Vojske i javnosti, ali i uspešne primene različitih promotivnih aktivnosti.

Neadekvatan odnos predstavnika Vojske prema javnosti može imati samo negativne konsekvence i po imidž Vojske.

Postoje izvesni problemi i kada su u pitanju interne komunikacije u vojnoj organizaciji. Aktivnosti su, u najvećoj meri, oslonjene na samoinicijativu menadžerskog kadra (komandante jedinica), koji, često, ima ograničene mogućnosti, ali i znanja iz oblasti marketinga. Tako se one svode na obaveštavanje pripadnika Vojske, njihovo motivisanje, razvijanje opšte kulture, instrukcije za odnose sa mas-medijima... i usmerene su težišno ka osnovnim jedinicama i vojničkom sastavu.

Sem potrebe za uspostavljanjem kvalitativno novih odnosa sa javnošću, promotivni miks VA, u obezbeđenju kadrova saobraćajne struke, zahteva i prisustvo ostalih oblika promocije, ali upotrebljenih na pravi način i u pravom trenutku. Odnosi sa javnošću su promotivni 
oblik koji mora biti konstantno prisutan $\mathrm{u}$ marketing-miksu VA, ali i drugi oblici promocije, kao što je propaganda ili direktni marketing, treba da budu stalnog, eventualno povremenog karaktera.

Propaganda, i kao institucionalna i kao propaganda proizvoda, usmerena ka ciljnim grupama, mora biti ravnomernog intenziteta da bi bila efikasna. Posebno važnu ulogu može odigrati adekvatan oblik tzv. misionarske promocije, kojom bi se povećao publicitet i stekla pozitivna društvena reputacija Vojske (apelovanjem na patriotizam, tradiciju, humanost i šire društvene vrednosti).

Mediji u propagandnim aktivnostima VA, putem kojih će se propagandna poruka preneti ciljnom segmentu, takođe, moraju biti pažljivo odabrani. Novine i časopisi veoma su pogodni mediji, prvenstveno zbog svog tiraža, ali i zbog geografske fleksibilnosti. Pri tome su časopisi veoma efikasni i u internom marketingu. Do sada je u tu svrhu korišćeno nekoliko časopisa, ali je moguće proširiti domen njihovog delovanja. Svrsishodno bi bilo da ti časopisi, donekle modifikovanog sadržaja, budu dostupni i ciljnim segmentima tržišta i široj publici. Kao takvi, mogu postati veoma važan medij eksternog marketinga.

O televiziji, kao mediju, suvišno je govoriti. Međutim, Vojska ga do sada nije eksploatisala u dovoljnoj meri, a VA gotovo nikako. Vojska (Jugoslovenska armija, Vojska Jugoslavije, Vojska Srbije i Crne Gore...) već decenijama ima samo jednu televizijsku emisiju u toku sedmice, i to u neatraktivnom terminu i na programu koji nije u vrhu liste gledanosti. Zanimljivo je analizirati moguće efekte obogaćivanja i modernizovanja sadržaja te emisije, i preispitati promenu termina $\mathrm{i}$ programa emitovanja, a možda i televizije na kojoj se emituje. U prilog tome govore i podaci o gledanosti emisija čiji su tematski sadržaji bliski vojnim aktivnostima, a koje su emitovane u drugom terminu i na drugim programima.

I ostali mediji: filmovi, reklame, katalozi, prospekti, takođe, mogu biti efikasni za prenošenje propagandnih poruka, ali povremeno i za relativno kratak period ( $u$ vreme završetka školske godine $u$ srednjim školama, npr.).

U skladu sa zahtevima vremena i oblici direktnog marketinga ne smeju se zapostaviti. Konkretno, aktivnosti VA treba usmeriti ka pojedinim srednjim školama i njihovim najboljim učenicima. $\mathrm{Na}$ osnovu rezultata školovanja studenata VA, iz više generacija, analizom baze podataka kojom raspolaže VA, moguće je utvrditi konkretno koje srednje škole daju kvalitetan potencijalni kadar i, zatim, ka tim školama usmeriti težište svojih marketinških aktivnosti. Svoju ponudu najboljim učenicima tih škola Vojna akademija može prezentovati poštom (raznim katalozima i drugim štampanim medijima), telefonom, e-mailom.

Od ostalih oblika promocije moguća su i učešća na sajmovima i izložbama, organizovanje taktičko-tehničkih zborova, kao i određeni vidovi unapređenja prodaje organizovanjem plaćenih poseta najboljih srednjih škola VA, odnosno, poseta marketing-timova VA određenim školama, kao vid lične prodaje i sl.

Mogućnosti SbSl u eksploataciji instrumenata promocije su velike. Njihovim pažljivim planiranjem i realizacijom SbSl bi zaokružila set osnovnih instrumenata marketinga i na tržište izašla kao 
ozbiljan i dominantan činilac. U planiranje i realizaciju promotivnih aktivnosti treba da budu uključeni svi pripadnici SbSl Vojske, a ne samo njen segment $u$ VA, ali i ostali pripadnici Vojske (prvenstveno po vojnoteritorijalnim odsecima).

Jedino sveobuhvatnim prihvatanjem marketing-koncepta i strateškim pristupom formiranju adekvatnog marketing-miksa, uz angažovanje svih resursa SbSl, i drugih, moguće je obezbediti potreban kadrovski potencijal. Pasivan pristup i prepuštanje slučaju neminovno vodi padu kvaliteta i deficitu kadra, što jedna ozbiljna i važna organizacija, kao što je Vojska, ne sme dopustiti.

\section{Zaključak}

Osnovni zadatak marketinga u organizacijama profitnog tipa jeste plasiranje i prodaja proizvoda. Danas je taj zadatak dobio novu dimenziju u humanitarnim i društvenim institucijama. Shodno savremenim marketinškim trendovima, i neprofitno orijentisane organizacije na domaćem tržištu počele su da preuzimaju i primenjuju marketinške metode i tehnike iz oblasti profitnog sektora.

Za adekvatnu i pravilnu primenu marketing-akcija, od presudnog su značaja pravilno shvatanje marketing-filozofije, sistemski pristup u rešavanju marketing-problema i spremnost da se prihvate marketing-tehnike iz profitnog sektora. Teorija marketinga služi se marketing-miksom (formulom 4P), pri čemu je mera uspeha uspostavljanje ravnoteže između njegovih instrumenata.

Ako se u neprofitnim organizacijama program smatra proizvodom, a spoljašnji imidž organizacije ,pakovanjem“, cilj marketing-menadžera se, prvenstveno, ogleda u diferenciranju programa od konkurentskih. Sa aspekta obezbeđenja kadrova za potrebe Vojske, odnosno njene SbSl, proizvod - program koji se nudi tržištu jeste program školovanja u VA.

Opšti pad vrednosti u društvu, protekla ratna zbivanja na prostorima prethodne Jugoslavije i uloga Vojske u njima, uz nefleksibilne marketing-aktivnosti Vojske, doveli su do pada interesovanja za program školovanja u VA, kao i do pada imidža celokupne vojne organizacije. Sve se to reflektovalo i na manjak kvalitetnog kadra za potrebe SbSl. Aktuelni problemi, sa kojima se SbSl danas suočava, zahtevaju postojanje i dobru koordinaciju marketing-tima, koji će usmeravati svoje akcije u skladu sa reformskom politikom SbSl i Vojske.

Postavlja se pitanje: da li marketing u Vojsci može doneti i tržišnu logiku, koja će degradirati i vulgarizovati svrhu njenog postojanja? „Tržište“ i „potrošači“, u tom kontekstu, poprimaju drugačije značenje i, kada se radi o vojnoj organizaciji i odbrani, ne treba ih posmatrati kao eksterni privredni činilac već kao partnera. Takav pristup tržištu treba da inicira svesno i usmereno delovanje ka ostvarivanju društveno prihvaćenih ciljeva u oblasti odbrane, a uz pomoć odgovarajućih mera, instrumenata $i$ aktivnosti. Sve planove na tom polju treba zasnivati na procesima istraživanja potreba, motiva i ponašanja korisnika.

Prihvatanje marketing-koncepta $u$ reformskim tokovima se, stoga, nameće kao neminovnost. Adekvatan marketing-miks, za potrebe obezbeđenja kvalitetnih kadrova, zahteva podrobnu analizu šansi i mogućnosti, a kao prvi koraci u 
definisanju njegovih instrumenata nameću se diferenciranje programa koji se nudi i njegovo repozicioniranje. Uz statusnu cenu takvog programa i kontinuiran rad na izgradnji imidža, a oslanjajući se na postojeće distributivne kanale i pojačane promotivne aktivnosti, program SbSl i VA može težiti liderskoj poziciji na tržištu.

Pravci daljeg razvoja marketinga u SbSl moraju se usmeravati ka građenju pogodne organizacione strukture i njenim tehničkim i materijalnim poboljšanjima, te stvaranju programa za marketing-edukaciju menadžmenta i strategij- skom planiranju marketing-projekata. Realizacija ovih aktivnosti zahteva i saradnju SbSl sa ostalim segmentima Vojske, ali i sa institucijama i ustanovama van Vojske, kako bi se zaokružila slika njenih marketinških delovanja.

Literatura:

[1] Filipović, V.; Kostić, M.: Marketing menadžment (teorija i praksa), Fakultet organizacionih nauka, Beograd, 2001.

[2] Milisavljević, M.; Maričić, B.; Gligorijević, M.: Osnovi marketinga, Centar za izdavačku delatnost Ekonomskog fakulteta u Beogradu, Beograd, 2005.

[3] www.netmba.com

[4] ccmr-bd.org

[5] Bojović, M.: Vojska pred očima javnosti, Interpres, Beograd, 1999. 